 \\ SENRA, ANA HELOISA; MELLO, EVANDRO DE; LIMA, LUCIANA DE SÁ DE; AMARAL, MARIA APARECIDA DO \& PILAR, PATRÍCIA OLIVEIRA
}

\section{Inclusão e singularidade: um convite aos professores da escola regular}

\author{
Belo Horizonte: Scriptum, 2008, 136 p.
}

\author{
Jácia Santos \\ Renata Nunes Vasconcelos
}

\begin{abstract}
()
livro é resultado da experiência vivida pelos autores - Ana Heloisa Senra, Evandro de Mello, Luciana de Sá de Lima, Maria Aparecida do Amaral e Patrícia Oliveira Pilar - na questão da inclusão de alunos com deficiência na escola regular. $\mathrm{O}$ fato de esses autores advirem de áreas de conhecimento afins, mas diversificadas, garante a interdisciplinaridade e riqueza do livro, o qual se apresenta dividido em três partes.

Na primeira parte, os autores, por meio de uma abordagem histórica, vão demonstrando que desde os primórdios da civilização vemos reproduzir, de diversas maneiras e sob várias estratégias, a exclusão dos portadores de necessidades especiais. A deficiência, desde o início, esteve ligada à noção de deficit, de falha, de disfuncionalidade, de desvio de conduta. As pessoas que se diferenciavam das outras por apresenta-

Mestre em Educação pela Universidade Federal de Minas Gerais.

- Doutora em Educação pela Universidade Federal de Minas Gerais; pró-reitora de extensão da Universidade Estadual de Minas Gerais.
\end{abstract}

256 Estilos da Clínica, 2010, Vol. 15, n 1, 256-261 
rem alguma anomalia recebiam algum tipo de classificação. Nos séculos XVI e XVII, por exemplo, conforme nos contam os autores, eram classificados como monstros. Já no século XVIII, os indivíduos que desviassem da conduta esperada pela família, pela escola, pela igreja eram chamados de indivíduos a corrigir. Surgia-se, assim, a ideia de anomalia, tudo corroborado pela medicina que atestava que a deficiência era uma condição determinada pela anomalia de diferentes funções orgânicas ou funcionais e, consequentemente, os indivíduos deficientes eram declarados doentes. A deficiência era vista como um problema inato do indivíduo e, por isso, entendia que o próprio indivíduo deveria se adaptar a ela.

Nesse contexto, conforme ressaltam os autores, o modelo médico de deficiência favoreceu uma resistência da sociedade em aceitar a necessidade de mudar suas estruturas e atitudes para incluir em seu seio os deficientes. Nessa mesma época, inúmeras instituições foram surgindo com o objetivo de "curar" os indivíduos considerados deficientes a fim de integrá-los na sociedade em condições semelhantes às pessoas consideradas normais. Porém, conforme os autores, a ineficiência dessas instituições e as denúncias acerca da segregação e da estigmatização que elas consolidavam fez surgir o Movimento de Integração, o qual buscou inserir os deficientes nos sistemas sociais gerais, tais como a educação, o trabalho, a família e o lazer. Vale lembrar que esse Movimento, segundo os autores, ainda se fundamentava no modelo médico de deficiência e, em consequência disso, reproduzia uma seleção, dessa vez socioeconômicocultural. Até a década de 1990, o campo da educação ainda exibia, no tocante à clientela com deficiência, uma submissão ao discurso médico, que vinha reproduzindo, em sua história, práticas precárias para a reabilitação dos deficientes. Essas práticas foram criticadas por suas consequências excludentes e segregatórias culminando em críticas ao Movimento de Integração no âmbito da escola.

Mais tarde o Movimento de Inclusão vai apresentar o caráter alienante do discurso médico propondo um modelo social de deficiência que se fundamenta no entendimento de que os problemas da pessoa com deficiência estão tão nela quanto na sociedade. Esse Movimento, visando eliminar toda e qualquer forma de exclusão, passa a exigir do governo e da sociedade recursos variados que garantissem a autonomia da pessoa com deficiência, o exercício de suas potencialidades e a expressão de suas singularidades. O Movimento de Inclusão sustenta o ideal acerca das potencialidades de a 
sociedade se adaptar para poder incluir em seus sistemas sociais gerais as pessoas com deficiências, enquanto, simultaneamente, estas se preparariam para assumir seus papéis na sociedade.

A inclusão, nesse contexto, ganha força com a Declaração de Salamanca, que se constitui em um importante documento sobre princípios, políticas e práticas relativos às necessidades especiais. Tal documento estabelece que as pessoas com necessidades educativas especiais devem ter acesso às escolas comuns, as quais deverão integrá-las numa pedagogia centralizada na criança, capaz de atender às suas necessidades. Porém, para os autores, novamente houve a insistência em se construir o "para-todos" por meio de uma categorização particular. Em um primeiro momento, não houve a capacitação das escolas regulares para o atendimento de todas as crianças e, consequentemente, muitas delas continuaram esquecidas, maltratadas e reprovadas.

Como se pode perceber, nessa primeira parte os autores demonstram claramente que a escola especial consolidou-se como prática de segregação, uma vez que se fundamentava em um discurso médico de deficiência, que concebia o indivíduo deficiente como um ser carente de cuidados e incapaz de produzir sentidos para a sua existência.

$\mathrm{Na}$ segunda parte do livro, os autores discutem o processo de implementação da Educação Inclusiva no contexto da educação brasileira ressaltando a necessidade de transformar o sistema educacional brasileiro e de propor ações que respondam aos objetivos de uma prática educacional inclusiva que leve em consideração a singularidade de cada aluno, não eliminando as diferenças em favor de uma suposta igualdade. Os autores se posicionam contrários à ideia da inclusão que negligencia as especificidades dos estudantes com necessidades especiais em classe comum, e afirmam a necessidade da reorganização do sistema escolar como um todo, em que adaptações de grande e pequeno porte devem ser efetivadas. Essas adaptações de "pequeno e grande porte", previstas nas Diretrizes Curriculares Nacionais para a Educação Especial (MEC/SEESP, 1998), como é o caso do Projeto Político Pedagógico, na organização escolar e criação de serviços de apoio e mesmo as mudanças curriculares e a programação das atividades elaboradas pelo professor são destacadas pelos autores como imprescindíveis para a garantia do direito à inclusão.

No entanto, vale destacar que nas Diretrizes a utilização de expressões como "significativas ou não significativas", "pequeno e grande porte" é representante de um campo discursivo que se assenta na polarização. Polarização que pouco colabora quando estamos falando 
de inclusão de indivíduos diferentes que rompem com essa cadeia discursiva. O diferente, no caso da pessoa com necessidades especiais, desorganiza essa cadeia por não se enquadrar nela, apesar de todo o esforço normalizador por fazê-lo. As Diretrizes, portanto, ainda se fazem com essa lógica linear ainda presente inclusive no discurso pedagógico.

$\mathrm{Na}$ terceira parte, os autores dão dicas de como o leitor pode aproveitar os conhecimentos adquiridos com a leitura do livro para criar possibilidades educativas para os alunos portadores de necessidades especiais. Essa terceira parte do livro é um fechamento da primeira e segunda parte. Para os autores, se queremos construir uma educação onde todos aprendam juntos, é preciso lançar um novo olhar sobre o conceito de deficiência, pois durante muito tempo acreditou-se que os indivíduos com deficiência primeiro necessitariam de cuidados clínicos, para ter sua deficiência amenizada e, assim, pudessem aprender. Segundo os autores, a deficiência não tem que ser definida pela limitação do sujeito, como algo intrínseco a ele, mas deve ser entendida na lacuna entre aquilo que o sujeito necessita e aquilo que o ambiente ou a ação pedagógica oferece. Nessa concepção, o essencial é criar possibilidades educativas as quais sejam capazes de favorecer a aprendizagem, criando recursos de que os alunos possam fazer uso e possam potencializar suas habilidades. Como 
inclusão, esclarecendo dúvidas conceituais para estudantes, professores e pesquisadores interessados no assunto. Por isso recomendamos sua leitura.

\section{REFERÊNCIAS}

Lacan, J. (2003). Proposição de 9 de outubro de 1967 sobre o psicanalista da escola. In J. Lacan. Outros escritos. Rio de Janeiro: Jorge Zahar.

MEC/SEESP, (1998). Diretrizes curriculares nacionais para a educação especial. Brasília/DF.

santosecia@yahoo.com.br renatanunesv@terra.com.br

Recebido em junbo/ 2010. Aceito em julbo/ 2010. 